\title{
An Intergeneration Solidarity Perspective on Succession Intentions in Family Firms
}

Entrepreneurship Theory and Practice

00(0) I-28

(C) The Author(s) 2020

Article reuse guidelines: sagepub.com/journals-permissions DOI: | 0.1 | $77 / \mid 042258720956384$

journals.sagepub.com/home/etp

\author{
Daniela Gimenez-Jimenez' (미, Linda F. Edelman², \\ Tommaso Minola ${ }^{3}$ (i), Andrea Calabrò ${ }^{4}$ (i), and Lucio Cassia ${ }^{3}$
}

\begin{abstract}
In enterprising families, the family, as a social institution, is the foundation of the family business. However, in enterprising families, intergenerational succession remains problematic. Using intergenerational solidarity theory, and data from the 2013 Global University Entrepreneurial Spirit Students Survey (GUESSS; $N=18,576$ ), our findings indicate that affective commitment partially mediates the relationship between family business exposure and offspring's succession intentions. We also find that this relationship is stronger for sons than for daughters, while birth order has no effect. Implications for theory and practice are discussed.
\end{abstract}

\section{Keywords}

enterprising families, intergenerational solidarity, succession intentions, family business exposure, affective commitment, gender

JEL Classification: J12, J16, J24, L26

Enterprising families are families that run one or more businesses and have an intent to grow these businesses with the family as the foundation of the enterprise (Nordqvist \& Melin, 2010). They are unique in that the family directs the enterprising activities of the family business and the individual family members, with the goal of maximizing wealth for current and future generations of the family (Habbershon \& Pistrui, 2002). Yet, family businesses are, by their nature, complicated due to the dynamics within the family unit. These dynamics can affect business performance and growth, as well as family members' well-being (Umans et al., 2019).

Despite the goals and directives of the enterprising family, intergenerational succession remains problematic (De Massis et al., 2008; The Economist, 2015). Recent studies found that,

\footnotetext{
'Technische Universität München, Alte Akademie 14, 85354 Freising, Germany

${ }^{2}$ Bentley University, 319 Adamian Academic Center, Waltham, MA, USA

${ }^{3}$ University of Bergamo, Department of Management, Information and Production Engineering (DIGIP) and Center for Young and Family Enterprise (CYFE), via Pasubio 7b, 24044 Dalmine, Bergamo, Italy

${ }^{4}$ IPAG Business School, 4 bd Carabacel, 06000 Nice, France
}

\section{Corresponding Author:}

Daniela Gimenez-Jimenez, Technische Universität München, Alte Akademie 14, 85354 Freising, Germany.

Email: daniela.gimenez@tum.de 
often, children of entrepreneurial families do not intend to take over their parents' businesses (Zellweger et al., 2011). This lack of intergenerational succession may lead to discontinuity in governance and can lead to lower performance or firm failure.

Significant work focuses on understanding the impact of family characteristics on intergenerational succession. These studies have found that factors such as clarity of succession plans, preparation level of the successor, parental roles, level of trust in the successor's abilities, and family rivalries, influence succession intentions (Daspit et al., 2016; Handler, 1992, 1994; Miller et al., 2003; Sharma et al., 2003b; Stavrou, 1999). Other studies have focused on succession from the perspective of the offspring or potential successor (Birley, 1986, 2002; Schröder et al., 2011). These studies have found that succession is more likely to occur when intergenerational relationships are harmonious (Venter et al., 2005), career interests are aligned with the family enterprise (Dawson et al., 2015), and when successors have high internal locus of control (Zellweger et al., 2011).

In our paper, we address the overarching question: In the context of the enterprising family, what are the intergenerational family mechanisms that influence children's succession intentions? However, unlike other studies, we drill down on the paradoxical role played by family business exposure, that is children's exposure to entrepreneurship and their experience in the family firm (Carr \& Sequeira, 2007). Some research finds that family business exposure may lead to the transmission of positive parental values and hence is positively associated with succession intentions (Carr \& Sequeira, 2007). Other research suggests that family business exposure may generate feelings of inferiority and excessive pressure in the potential successor that leads them to choose other careers (Mungai \& Velamuri, 2011; Wang et al., 2018). This inconsistency suggests the importance of exploring the psychological mechanisms between exposure and succession intentions, as well as family and individual level contingencies. Therefore, we ask the specific research questions: In the context of the enterprising family, what is the role of affective commitment in the relationship between family business exposure and succession intentions? and then: In the context of the enterprising family, what is the moderating role of gender and birth order in the relationship between family business exposure and affective commitment? We address these questions by turning to the recent work on family science (Jaskiewicz et al., 2017) and adopting an intergenerational solidarity theory perspective (Bengtson, 2001; Bengtson \& Roberts, 1991) to explore succession intensions, in the context of the enterprising family.

To test our ideas, we use data from the 2013 Global University Entrepreneurial Spirit Students Survey (GUESSS), selecting only respondents coming from an enterprising family, to a usable sample size of 18,576 from 33 countries. The GUESSS project is a study of university students, which records students' entrepreneurial experiences, beliefs and behaviors on a biannual basis. It has been widely used in entrepreneurship research (Edelman et al., 2016; Sieger \& Minola, 2017; Zellweger et al., 2011). It is particularly appropriate to study the effects of the enterprising family in that it captures a number of dimensions regarding the family, the firm, and their effect of young family members' career intentions. In addition, most children do not join the family firm fulltime until after they have completed their education, which is sometime between their eighteenth and twenty-eighth birthdays (Birley, 1986; Chadwick \& Ward, 1987; Handler, 1989). University students are the ideal sample to study the effect of family business exposure on succession intentions, as cognitively they are at an age where career intentions are forefront, and it is at this time that young adults are making important career choices with long-term implications (Stavrou, 1999).

Our paper contributes to the literature on family business exposure in the context of the enterprising families. First, our use of intergenerational solidary theory helps us to understand the connection between the family and the family business. Specifically, we advance affective commitment as the intervening mechanism between family business exposure and succession 
intentions using this solidarity lens. This allows us to address the inconsistencies and conflicting findings in the previous literature (Wang et al., 2018), by finding that exposure in conjunction with commitment leads to succession intentions. Finally, we disambiguate the effect of family business exposure leading to affective commitment by focusing on the moderating role of gender and birth order. On the ensuing pages, we present our theory and hypotheses, test our model, present our results and discuss our findings and their implications.

\section{Theory and Hypotheses}

\section{Family Business Exposure}

Family business background refers to the generic influence exerted on children by their growing up in an enterprising family context (Schröder et al., 2011). However, children may be more or less actually connected to the family business depending on the bundle of experiences, values and beliefs that they accumulate by working in their family firm (McMullen \& Warnick, 2015). Carr and Sequeira (2007) distinguish "family business exposure" as the engagement in shared activities around the family firm, or by having at least one close family member, such as a parent, who owns and manages the family firm, and is operationally involved in it. It is the specific and pronounced influence of the family business context on children, which includes closeness, identification and learning (Stavrou, 1999; Wang et al., 2018). Family business exposure is considered to have an overall positive effect on transgenerational entrepreneurship (Carr \& Sequeira, 2007).

However, family business exposure has a dark side. Some research has found that family business exposure weakens the positive impact of perceived parental entrepreneurial rewards on entrepreneurial intentions (Wang et al., 2018). Specifically, findings indicate that when the enterprise is unsuccessful, then exposure leads to a negative image of entrepreneurial career, or conversely, if the firm is too successful, exposure may generate feelings of inferiority and excessive pressure (Criaco et al., 2017; Pittino et al., 2018). In our work, we answer recent calls by Wang et al. (2018), who suggest that there are additional and currently unaccounted for factors in the exposure-succession intentions relationship, by exploring the mediating role of affective commitment. We ground our arguments in intergenerational solidarity theory, which we turn to next.

\section{Family Science and Intergenerational Solidarity Theory}

Intergenerational solidarity theory falls under the broad umbrella of family science (for a comprehensive review of family science theories and their impact on family business research, please see Jaskiewicz et al., 2017). It addresses the ways in which family members organize their lives and pursue their goals in the context of intergenerational "shared lives" (Jaskiewicz et al., 2017). In particular, intergenerational solidarity theory focuses on children's post-adolescent phase, or early adulthood, and stresses that socialization occurs within families as a means to assist children in adopting social roles and behaviors (Brim, 1968). With its roots in sociology, the theory explains family integration (Mancini \& Blieszner, 1989) and intergenerational family relationships (Bengtson, 2001). It is based on the empirical observation that "the extended family maintains cross-generational cohesion through modern communication and transportation technologies that allow contact, in spite of centrifugal social forces that distance family members" (Silverstein \& Bengtson, 1997, p. 431).

Intergenerational solidarity is a multifaceted, multidimensional construct comprised of six different conceptual solidarity dimensions of parent-child interaction. These include: normative (commitment to roles and obligations), functional (help and exchange of resources), consensual 
(agreement on values), associational (frequency and patterns of interactions), structural (opportunity for interaction, based on family structural element such as size and proximity of members), and affectual (type and degree of positive sentiments, and reciprocity) solidarities (Bengtson, 2001; Roberts et al., 1991). These solidarity dimensions provide a valid and reliable tool for assessing the strength of intergenerational bonds (Mangen et al., 1988).

Empirical validation of the theory indicates that solidarity is not a unidimensional metaconstruct, instead its elements co-vary (Bengtson \& Roberts, 1991), and that its dimensions are not simply additive (Silverstein \& Bengtson, 1997). While the goal of intergenerational solidarity theory is to provide a comprehensive structural model to explore the interrelationships of the various solidarity dimensions, the nature of the construct allows for testing the interrelationships of one or few of the dimensions separately. In doing so, the theory has allowed researchers to reflect on "the complexity and contradictions of family life" (Silverstein \& Bengtson, 1997, p. 432).

In sum, intergenerational solidarity theory offers a solid theoretical framework through which researchers can explore transgenerational entrepreneurship (Jaskiewicz \& Dyer, 2017), as well as the complex relationship among children, family and firms (Combs et al., 2020). It is a particularly appropriate for our paper because "the solidarity paradigm represents one of the few longterm efforts in family sociology to develop and test a theory of family integration" (Silverstein \& Bengtson, 1997, p. 432). Combs et al. 2020, p. 49) argues that "rather than studying individual attributes of intergenerational relationships in isolation (e.g., conflict), this theory offers a unifying framework for holistically capturing such relationships [in the family business context]." The application of intergenerational solidarity constructs to intergenerational succession represents an "obvious avenue for future enquiry" (Jaskiewicz et al., 2017, p. 328),"[and, b]ecause higher intergenerational solidarity increases children's self-efficacy and self-efficacy is an important predictor of entrepreneurship, intergenerational solidarity might explain why some families produce entrepreneurs for generations" (Jaskiewicz et al., 2017, p. 328). In Table 1, we review the six forms of intergenerational solidarity and provide examples of their use in family business research. Next, in our theoretical development, we explore their impact on the exposurecommitment-succession intentions relationship. In Figure 1, we present our theoretical model.

\section{Intergenerational Solidarity Theory and the Family Business Exposure-Affective Commitment-Succession Intentions Relationship}

\section{Associational Solidarity}

Associational solidarity refers to the frequency of intergenerational interactions, including faceto-face contacts, conversations, telephone call, emails as well as common activities such as special occasions (Silverstein \& Bengtson, 1997). It emerges through the frequency of intergenerational interactions and common activities in the family, including learning, informal dialogues and exchange of views. In the context of enterprising families and family businesses, associational solidarity derives from the children's interaction with their parents that includes transgenerational transmission of information, beliefs and resources and occurs to a great extent around the daily life of the firm (Moore et al., 2002). Examples of associational solidarity include children working in the family firm and witnessing family members as part of the top management team or board of directors. Hence, children experiencing associational solidarity coming from family business exposure will see succession in the family firm as a means to perpetuate strong intergenerational relationships. Building on this and succession intentions literature 


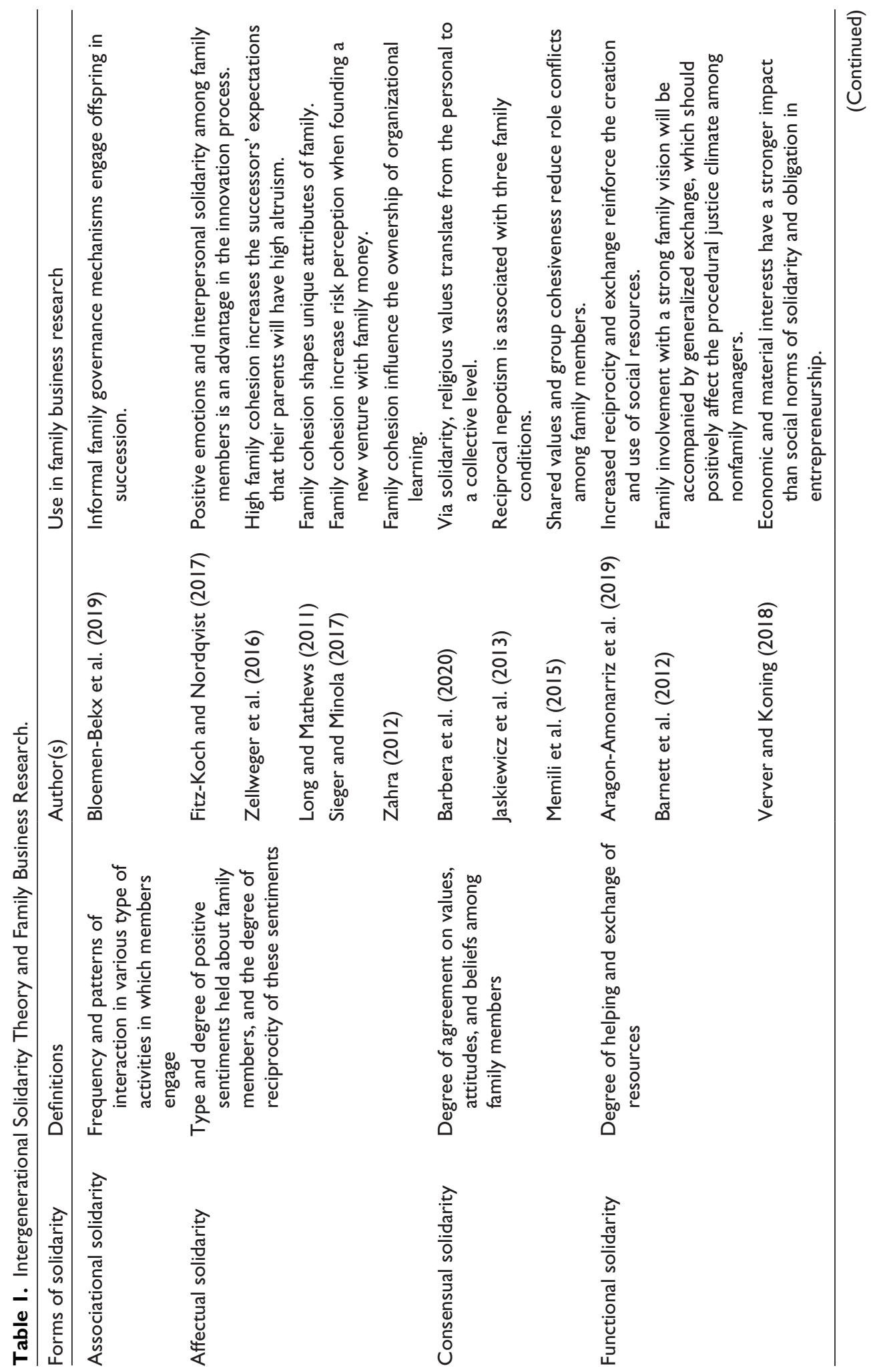




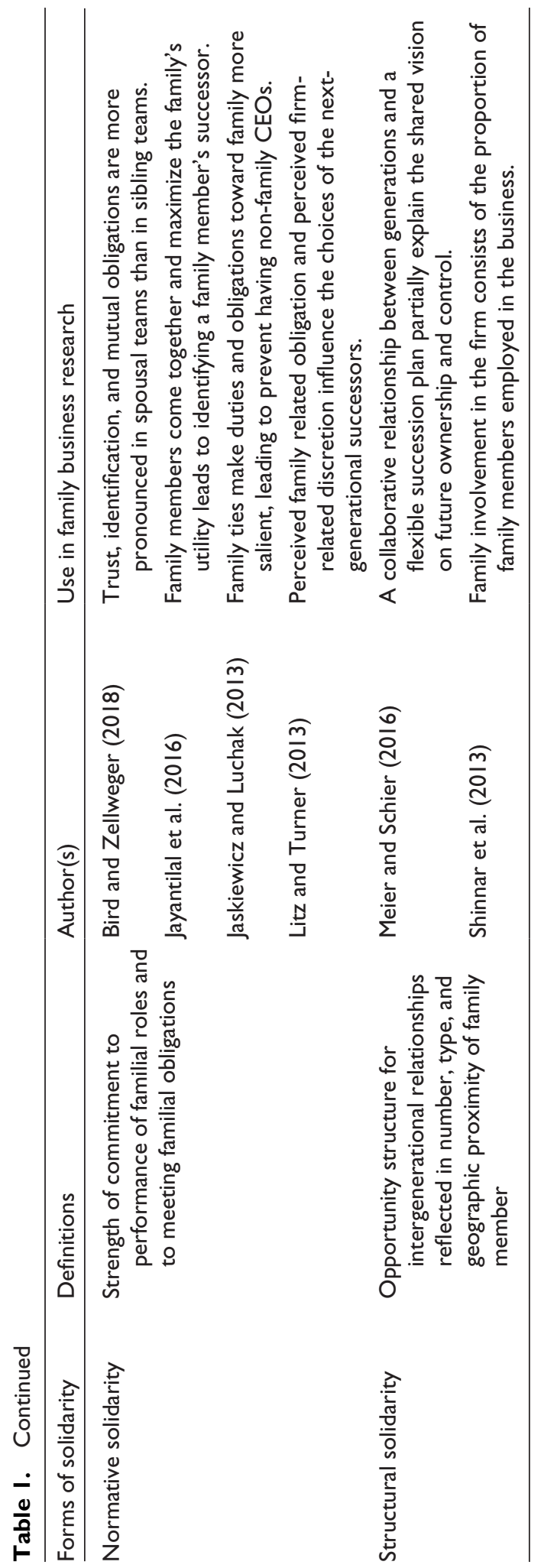




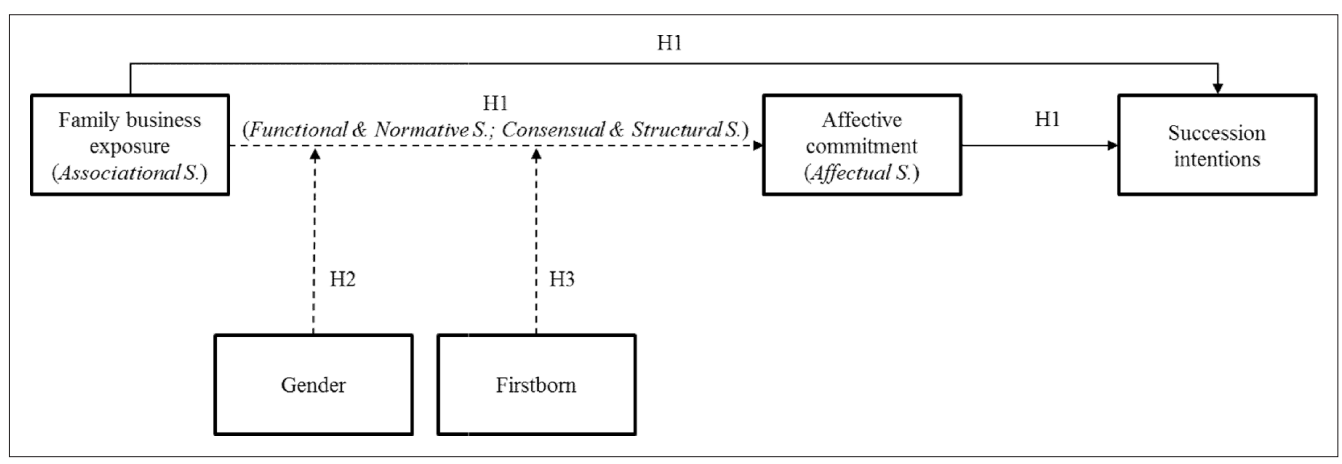

Figure I. Theoretical model.

Note. Dashed lines are framed in the Intergenerational Solidarity.

(De Massis et al., 2008; Umans et al., 2019), we advance that children with higher degree of family business exposure will manifest stronger succession intentions.

\section{Affectual Solidarity}

According to intergenerational solidarity theory, affectual solidarity explores the emotional side of the relationship between parents and their offspring. It measures the type and degree of positive sentiments and reciprocity held by family members (Bengtson \& Roberts, 1991) and takes the form of cohesion (Silverstein \& Bengtson, 1997). In the context of enterprising family, we claim that affective commitment towards the family firm proxies' affectual solidarity in the family. It does this through psychological ownership, which is the state of mind in which individuals feel as though the target of ownership is "theirs" (i.e., "It is MINE!"; Pierce et al., 1991). In the context of the family firm, psychological ownership emerges from two dimensions that are closely related to family firm exposure (Townsend et al., 2009), i.e. intimate knowledge (Pierce et al., 2001) and identification (Henssen \& Ikävalko, 2014). Since psychological ownership is a direct antecedent of affective commitment (Sieger et al., 2013), we claim that affective solidarity towards the family manifests as an affective commitment towards the firm.

Affective commitment is a positive feeling of identification with, attachment to, and involvement with, the organization (Allen \& Meyer, 1990). It has received a large amount of attention in management, organizational behavior and human resource management research (Meyer \& Herscovitch, 2001), as well as in the entrepreneurship and family business literatures (Dawson et al., 2015; Jaskiewicz et al., 2015). In the context of family firms, affective commitment has been expressed in terms of "strong belief in and acceptance of the organization's goals, combined with a desire to contribute to these goals, and the confidence in one's ability to do so." (Sharma \& Irving, 2005, p. 19).

In the next sections, we combine the family business literature with intergenerational solidarity theory logic to explain why intergenerational solidarity theory components motivate associational solidarity to turn into affectual solidarity, as illustrated in Figure 1.

\section{Functional and Normative Solidarity}

Functional solidarity refers to the degree of helping and resource exchange among family members, while normative solidarity describes the strength of commitment to familiar roles and 
obligations (Bengtson \& Roberts, 1991). These solidarity mechanisms begin with the exposure to the family business (associational solidarity) and then, given the intergenerational interaction between the child and family together with its firm, increases his or her identification and involvement with the firm (Dawson et al., 2015; Sharma et al., 2003a). Triggered by exposure, functional and normative solidarities positively relate to the level of affectual solidarity, and hence of affective commitment, albeit in two different ways.

Consider the case of an enterprising family. We observe strong functional solidarity in the case of balanced (i.e., reciprocal) exchange when there are available resources, time or effort put into the business. These are components of an indivisible "currency of intergeneration exchange" (Bengtson \& Roberts, 1991, p. 861), which is made of material, emotional and physical support. In this case, "love and money" are inseparable elements of the family relationships (Bengtson \& Roberts, 1991). This situation may occur, for example, when children are actively involved in the family firm. This exposure develops a strong commitment to the firm, which fuels the intergenerational transmission of entrepreneurship (Sørensen, 2007).

Conversely, in the case of unbalanced exchange, we may see children borrowing social or reputational capital from the family firm, with little to give back, in return for it. While these resources may be readily available, their use raises concerns over creating normative obligations. In line with predictions from intergenerational solidarity theory, this normative sense of obligation and reciprocity is likely to induce affectual solidarity toward the family members and, hence, affective commitment toward the firm. As a whole, when exposure acts upon children's cognition, in balanced exchanges functional solidarity influences affectual solidarity through positive sentiments while in unbalanced exchanges normative solidarity does so through norms of reciprocity.

\section{Consensual and Structural Solidarity}

Additionally, to understand the complex exposure-commitment relationship, we also need to build on consensual and structural solidarity dimensions from intergenerational solidarity theory. Recall that consensual solidarity is the level of agreement on values, attitude and beliefs, while structural solidarity is the level of familial interaction. We suggest that these solidarities are impressed upon potential successors through the numerous opportunities for interaction, given the propinquity of family members (associational solidarity). This is especially strong when family business exposure includes working and gaining experience in the family firm (CabreraSuárez et al., 2014), as that has the potential to imprint the family entrepreneurial legacies (Jaskiewicz et al., 2015). Both consensual and structural solidarities motivate children to join the family business and give meaning to their embeddedness in the (enterprising) family. Eddleston et al. (2012) indicate that "family to firm unity," which is another expression for cohesion and solidarity, facilitates trust and stewardship towards firm principals and employees by younger generation members leading to a strong belief in the family firm. This stewardship-based belief indicates a positive feeling of identification with, attachment to, and involvement with, the organization, which we refer to as affective commitment. In this way, family business exposure is a source that fuels the way in which children are emotionally attached to the family firm, by experiencing solidarity within the family.

In sum, we claim that, by activating different forms of solidarity, family business exposure will positively influence affectual solidarity, and its manifestation in the context of an enterprising family, affective commitment. In view of the well-known effect of affective commitment in the succession intention literature (Dawson et al., 2015; Sharma et al., 2003a), we argue that family business exposure will lead to affective commitment, which will lead to succession intentions. Therefore, we hypothesize: 
Hypothesis 1: There is a positive mediated relationship among family business exposure, affective commitment and succession intentions.

\section{The Moderating Effect of Gender and Birth Order on Affective Commitment}

Potential successors to the family firm might still experience different levels of affective commitment even at similar level of exposure. To understand these differences, we rely on the welldocumented cultural principle of primogeniture. This principle, which results in inequality in selection and inheritance, and has the potential to affect a child's perspective towards the firm. The primogeniture principle, with its long lasting historical and cultural roots (Beckert, 2007), is based primarily on gender and birth order. Thus, in the following we formulate two corresponding moderating hypotheses of the family business exposure-affective commitment relationship.

\section{Gender}

Sons and daughters have different experiences during their socialization process, due to prevailing gender norms (Glover, 2014; Hytti et al., 2017); hence, the use of a gendered lens to test the differential effects of family members' interaction and behaviors has become increasingly popular in the family business context (Nelson \& Constantinidis, 2017). Career intentions of daughters in particular are influenced by gender roles, which are formed at a young age through family and peer interactions (Decker et al., 2017).

Evidence shows that intergenerational solidarity dynamics vary based on the gender of the offspring (Silverstein \& Bengtson, 1997). Specifically, perceptions of obligations and reciprocity vary, based on the child's gender (Jaskiewicz et al., 2017). Consider that women often reduce their work time and/or accept lower wages in order to perform the caregiver role to members of their family (Cha, 2013). This has an intergenerational solidarity-based explanation. The solidarity that daughters experience is likely to lead to greater care and concern towards the family and its needs, than towards the family firm.

Given that gender roles are widely diffused and deeply rooted in most societies around the world (Eagly \& Wood, 2011; Powell, 2011), we argue that the stronger the intergenerational solidarity, the greater the obligation to put family first, especially for daughters (Starrels et al., 1995). In particular, norms of reciprocity will be stronger, while the imprinting of entrepreneurial legacies will be weaker. In sum, we argue that the degree to which children develop affective commitment towards the family business, following family business exposure is stronger for sons than for daughters. Formally:

Hypothesis 2: There are significant gender differences in the relationship between family business exposure and affective commitment, such that the relationship between family business exposure and affective commitment is stronger for sons than for daughters.

\section{Birth Order}

Following Jaskiewicz et al. (2017) who, drawing on family science theories, posit that birth order may be an important condition affecting the family-firm interface, we advocate that birth order is an important contingency to the family business exposure-affective commitment relationship. Yet, despite the extensive amount of research on birth order in the psychology literature 
(Sulloway, 1996; Zajonc \& Markus, 1975), in the entrepreneurship and family business literatures, birth order has received less attention. Brush (1992) found that firstborn sons and daughters were more likely to become business owners. Goldberg and Wooldridge (1993) found that firstborn children are more likely to identify with and emulate their parent's behavior. More recently, Calabrò et al. (2018) found that appointing a firstborn sibling to run the family firm is more likely when there is a high degree of socio-emotional wealth endowment, and that family firm has pre-succession performance below aspiration levels.

From an intergenerational solidarity theory perspective, we know that there is a direct relationship between family structural characteristics and exchanges of instrumental and financial support within families. Research on birth order finds that firstborn children have the freedom to choose their niche within the family, and that they tend to satisfy parental demands by displaying responsible, conscientious, and conservative behaviors (Sulloway, 1996). In particular, consensual solidarity will exert a stronger effect. In family business research, birth order explanations are appealing as competition among siblings early in life may have implications in later life as siblings contend scarce resources, such as competing for whom leads the family business (Sulloway, 1996). We argue that firstborn children will show a higher degree of affective commitment towards the family firm because of their family business exposure. Formally:

Hypothesis 3: There are significant birth order differences in the relationship between family business exposure and affective commitment, such that the relationship between family business exposure and affective commitment is stronger for firstborn than for subsequent siblings.

\section{Methods}

\section{Data Collection and Sample}

To conduct our study, we use data from the GUESSS project. GUESSS was initiated by the Swiss Research Institute of Small Business and Entrepreneurship at the University of St. Gallen in 2003 and currently includes 34 countries (Sieger et al., 2014). The GUESSS project has three primary goals: (1) to systematically observe the entrepreneurial intentions and activities of students; (2) to identify the antecedents and boundary conditions in the context of new venture creation and entrepreneurial careers in general; and, (3) to observe and evaluate universities' activities and offerings related to the entrepreneurial education of their students (for more details, see Zellweger et al. (2011)). Data from the GUESSS project have been used to explore family issues in the entrepreneurial context (Criaco et al., 2017; Edelman et al., 2016), the career intentions of students with family business backgrounds (Zellweger et al., 2011) and the family logics that successors face (Zellweger et al., 2016). In fact, GUESSS contains a large number of potential family firm successors (Zellweger et al., 2016).

The 2013/2014 GUESSS survey collected data on 109,026 students from 34 countries (Sieger et al., 2014). Our sample selection follows Nordqvist and Melin's (2010) definition of entrepreneurial family, which "refer[s] to the family as an institution, or social structure, that can both drive and constrain entrepreneurial activities" (p. 214). This definition of entrepreneurial family includes the concept of transgenerational entrepreneurship (Jaskiewicz et al., 2015; Jaskiewicz et al., 2017). We therefore limit our study to those children whose parents own a firm; as these are the only individuals for which the concept of enterprising family applies. Similar to Zellweger et al., 2016, we only included respondents who answered the question "are you parents currently self-employed?" using either "yes, my father," "yes, my mother," "yes, my father and mother." 
This procedure reduces our sample to 18,640 observations. We then excluded students' responses with missing data. This left us with a usable sample of 18,576 students from 33 countries. ${ }^{1}$

\section{Variables and Construct Measurement}

\section{Dependent Variable}

Succession intentions were measured on a 7-point Likert-type scale. The scale follows Liñán and Chen (2009) and ranges from 7 (strongly agree) to 1 (strongly disagree). As the scales were developed for testing entrepreneurial intentions rather than succession intentions, the GUESSS development committee slightly adapted the scale from the original wording. These items are "I am ready to do anything to take over my parents' firm," "My professional goal is to become a successor in my parents' firm," "I will make every effort to become a successor in my parents' firm," and "I am determined to become a successor in my parents' firm." The scales for the main variables of the theoretical model are reported in the Appendix.

\section{Explanatory Variable}

Family business exposure has been used to understand the level of exposure of children to the family business (Carr \& Sequeira, 2007; Stavrou, 1999). Respondents were asked the following questions: "Are your parents operationally involved in the company?" "Yes" is coded as 1, "No" is coded as 0 ; "Is your father or your mother the CEO?" "Yes" is coded as 1 , "No" is coded as 0 ; "Have you been working for the business of your parents/family?" "yes, I have" denotes "1" and " 0 " indicates, "no, I have not." Following Carr \& Sequeira, 2007, we created an index by summing the "Yes" responses. This variable ranges from 0 " that represents low family business exposure to " 3 " that indicates high family business exposure. ${ }^{2}$

\section{Mediating Variable}

The GUESSS development committee developed the scales for affective commitment. ${ }^{3}$ Meyer and Herscovitch (2001) argue that the elements of the mind-set of affective commitment are identity-relevance, shared values, and personal involvement. Our measure captures these three elements in the following way: identity relevance and personal involvement are captured by "I feel emotionally attached to this organization" and "I connect mainly positive emotions and feeling with the company", while shared values are captured by "tradition and history play a very important role in our family business." The three items are based on a 7-point Likert-type scale ranging from 1 (strongly disagree) to 7 (strongly agree). The items used are taken by Zellweger et al. (2016) and are similar to those in the previous literature on affective commitment in enterprising families and family businesses (Dawson et al., 2015).

\section{Moderating Variable}

Gender: To assess gender, we used a dummy variable, in which 1 denotes female and 0 indicates male.

Birth order: To capture the birth order, we follow birth order literature (Paulhus et al., 1999; Rohde, 2003; Sulloway, 2001). The variable is coded as 1 if the respondent is a firstborn and 0 if the respondent is the subsequent child, in other words, whether the child has an one or more older siblings. 


\section{Control Variables}

To account for other factors that influence children's future career choices, we included the following controls. Previous work has observed that age influence children's future career choices in particular, succession intentions (Minola et al., 2016). Therefore, we included age as a control variable (numeric variable that goes from 18 to 34 years old). Previous work has observed that marital status impacts entrepreneurial actions (e.g., Özcan, 2011), thus, we included marital status as control variable (dummy variable, coded as 1 represents single and living with a partner and 0 denotes married and divorced). Parker and Van Praag (2012) observed that the level of study affects entrepreneurial decisions. Thus, we control by level of study (categorical variable coded as 1 indicates undergraduate, 2 indicates graduate, 0 indicates doctorate and executive education). Researchers have observed that the field of study plays a role in family expectations in succession (Zellweger et al., 2016). Therefore, we included field of study as control variable (categorical variable coded as 1 represents business, economics, 0 includes natural science, medicine, social science and other). Individuals, who are only child, do not compete for the succession of the family firm, as they do not have any other person with whom to compete. Thus, we controlled by being an only child (dummy variable, coded as 1 represents being an only child and 0 denotes having siblings). Since exposure to parental role models affects children's entrepreneurial actions (Hoffmann et al., 2015), we controlled by parental self-employment (dummy variable, coded as 1 when both parents are self-employed, 0 when only the mother or the father is self-employed). Given that there are gender difference in which industries men and women start businesses (Anna et al., 2000), this might influence the decision to take over the family firm. Thus, we controlled by industry (categorical variable coded as 1 denotes trade, construction, manufacturing and other industry related, 0 indicates all type of services, such as information and technology, consulting, advertising, education, and training, tourism and gastronomy, health services, other services). Finally, we also controlled by country dummies to account for regional differences that may influence children's succession intentions (Sieger \& Monsen, 2015; Zellweger et al., 2011). Table 2 presents the descriptive statistics and the correlation among the variables in the study.

\section{Statistical Procedure}

We used structural equation modeling (SEM) to test our theoretical model. Due to the complexity of family interactions and the latent nature of our phenomena (e.g., affective commitment on succession intentions), we ran our full model by using SEM, to examine the ways in which family business exposure could influence children's succession intentions.

\section{Results}

\section{Descriptive Statistics and Main Findings}

In our sample, $57.70 \%$ of the respondents are female and $42.30 \%$ are male. $33.60 \%$ of our respondents study business or economics and the rest are studying a variety of other fields. Finally, $28.10 \%$ responded that only their mother or father is self-employed, whereas $71.90 \%$ answered that both parents are self-employed.

We checked our variables for multicollinearity and for reliability. The maximum variance inflation factor (VIF) value in our model is 1.17 , well below the cut-off of 10, indicating that there is not a multicollinearity issue in the model (Hair et al., 2006). In addition, as our dependent and mediating variables (succession intentions and affective commitment) are latent variables, we decided to run an exploratory and confirmatory factor analysis to ensure their validity and 


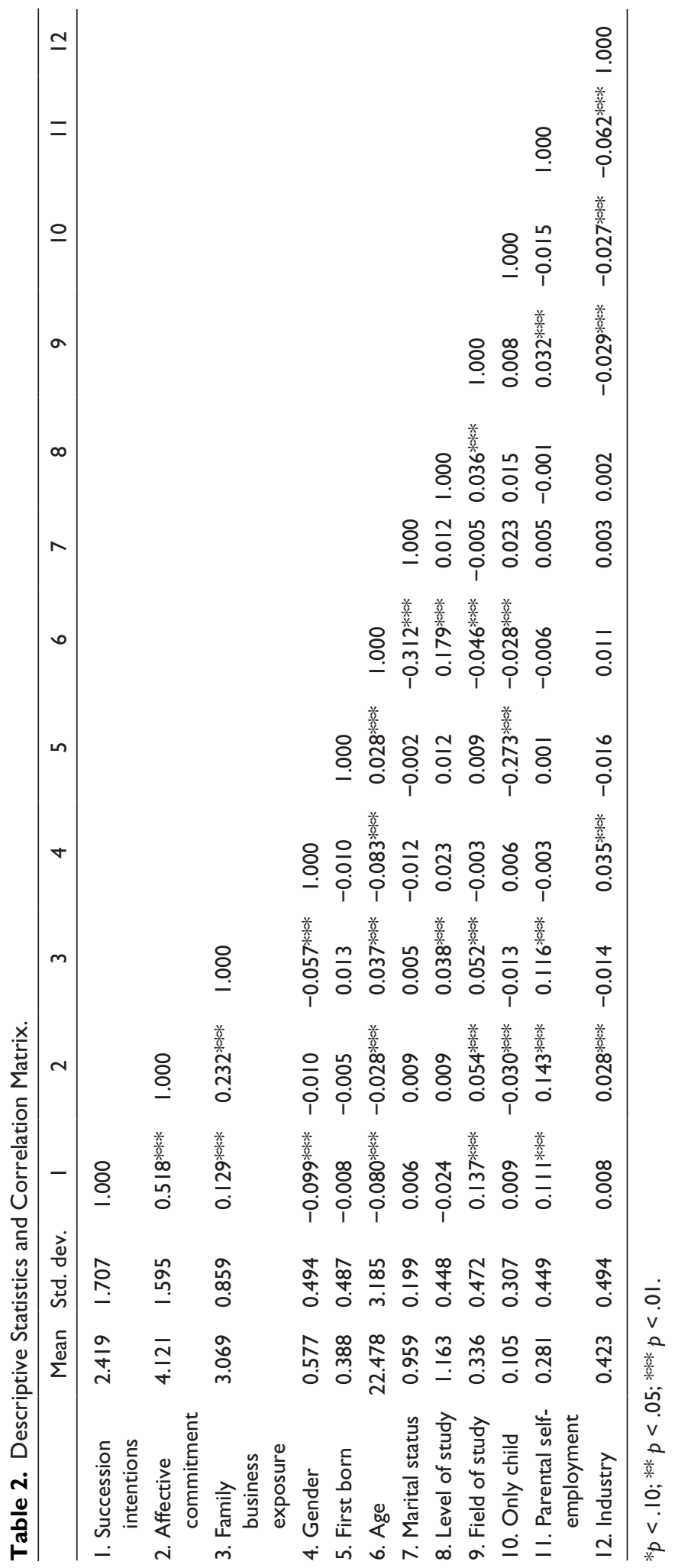




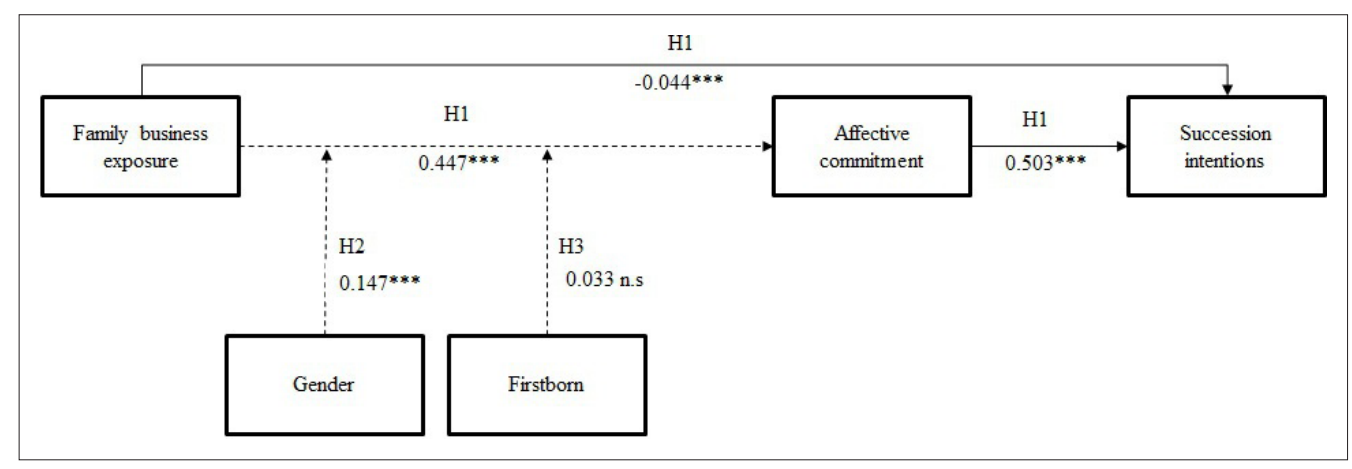

Figure 2. SEM model.

Note. The model includes all of the control variables, and it was estimated using STATA's SEM command. Estimation method maximum likelihood; log likelihood $=-43,8765.18, N=18,576 . * p<.10$; $* * p<.05$; $* * * p<.01$.

reliability. In the exploratory factor analysis, we observed that our four items of the succession intentions factor accumulate $92 \%$ of the variance, while the three items that capture affective commitment accumulate $68 \%$ of the variance. Afterward, we conducted a varimax rotation, and the results show that these items capture more than $80 \%$ of both factors. Second, we ran a confirmatory factor analysis (CFA) for our mediating and dependent variables. All indicators related positively and significantly to their intended construct $(p<0.001)$ and we observed no significant cross loading. The overall model shows a good model fit $(\mathrm{RMSEA}=0.083, \mathrm{CFI}=0.998, \mathrm{TLI}=$ $0.993, \mathrm{SRMR}=0.041)$ indicating construct validity. We also evaluated the construct reliability of the succession intentions and affective commitment constructs which are $\alpha=0.97$ and $\alpha=$ 0.76 , respectively. Both constructs exceeded the threshold level of 0.70 , representing good reliability and internal consistency of the measures (Nunnally \& Bernstein, 1994).

We tested for common method bias, as our variables used in the analyses are self-reported (Podsakoff et al., 2003). First, we used the Harman's one factor method. Using principal component method, we included the dependent, independent and control variables. The analysis indicates that there were five factors with eigenvalues greater than 2 and the first factor did not account for the majority of the variance (this factor accounted for $12.63 \%$ of the total variance). This indicates the absence of common method biases. We then introduced a common latent factor analysis in which we estimated model introducing a new latent variable to control for any influence that method could have on the estimated relationship (Podsakoff et al., 2003). The analysis did not find any evidence that common method bias influenced our results. The results of our structural equation analysis are shown in Figure 2.

The results provide support for some of our hypotheses. We found a small and direct effect of family business exposure on children's succession intentions $(\beta=-0.044, p<0.001)$, however, this effect is only marginal. The results also indicate that family business exposure has a stronger indirect effect that runs through affective commitment $(\beta=0.447, p<0.001)$, which then leads to a positive relationship between affective commitment and succession intention ( $\beta$ $=0.503, p<0.001)$. This result indicates that the effect of family business exposure on succession intentions is partially mediated by affective commitment, meaning that its effect goes through affective commitment mainly. Thus, this result overall supports Hypothesis 1 . Next, we observed that gender has a moderating effect on the relationship between family business exposure and affective commitment. Our findings indicate that being male strengthens the 
relationship between family business exposure and affective commitment $(\beta=0.147, p<0.001)$. Therefore, Hypothesis 2 was supported. However, when we interacted family business exposure with birth order dummy, our results did not show a significant effect ( $\beta=0.033, n . s$ ). Therefore, Hypothesis 3 was not supported. Table 3 summarizes the direct, indirect, and total effects of family business exposure on (i) succession intentions and (ii) affective commitment. The results show that the combined effect of family business exposure on succession intentions is 0.181 because it is the sum of the direct $(-0.044)$ and indirect effect $(0.225)$, where the indirect effect denotes the effect of exposure on succession intentions through the mediating variable, affective commitment.

In sum, we find that the positive relationship between family business exposure and children's succession intentions is partially mediated by affective commitment. In addition, we find that being male strengths the relationship between family business exposure and affective commitment, however birth order has no effect.

\section{Robustness Tests}

Additionally, to test the robustness of our model, we replicated our SEM model using bootstrap mediation procedure on 5,000 bootstrap interactions to obtain the estimate bias-corrected intervals. The bootstrap results confirm that the variables that were significant in the SEM model do not contain zeros. Table 4 shows the results of the coefficient interval in percentile and bias-corrected.

As an additional robustness check, we used the sample of individuals who only have siblings ( $N=16,546$ students). The results show that affective commitment fully mediates the relationship between family business exposure and succession intentions. This result is interesting because it shows that affective commitment plays an even more important role in the relationship between family business exposure and succession intentions when individuals have siblings than for individuals who are an only child. The results of the moderating variables did not change when compared to our main results. Gender significantly moderates the relationship between family business exposure and affective commitment, while firstborn does not have a significant influence on this relationship.

We also eliminated Brazil from the sample and then reran our model. We did this because Brazil is the country with the single largest number of responses $(n=2,312)$. The results do not change.

In another robustness test, we considered the effect of parents' performance in entrepreneurship (PPE) (Criaco et al., 2017) as a proxy for content and quality of family business exposure. We repeated the analysis for the subsample of students that have high level of PPE and for the one of students that have low level of PPE. The results indicate that PPE does not significantly alter the relationship among family business exposure, affective commitment and succession intentions. More specifically, family business exposure has a positive effect on affective commitment and affective commitment has a positive effect on succession intention in both low and high PPE cases. We consider that these results provide an indirect validation of the claim that - in our context - it is family business exposure per se that leads to positive affective solidarity considerations in children.

Finally, we repeated our analysis by testing our independent variable in different ways. We introduced our independent variable as a ranked variable in an OLS regression with robust standard errors. We also decomposed our independent variable to test the effect of it as ranked and each of the components without being an index. The results continue to support our main results. ${ }^{4}$ 


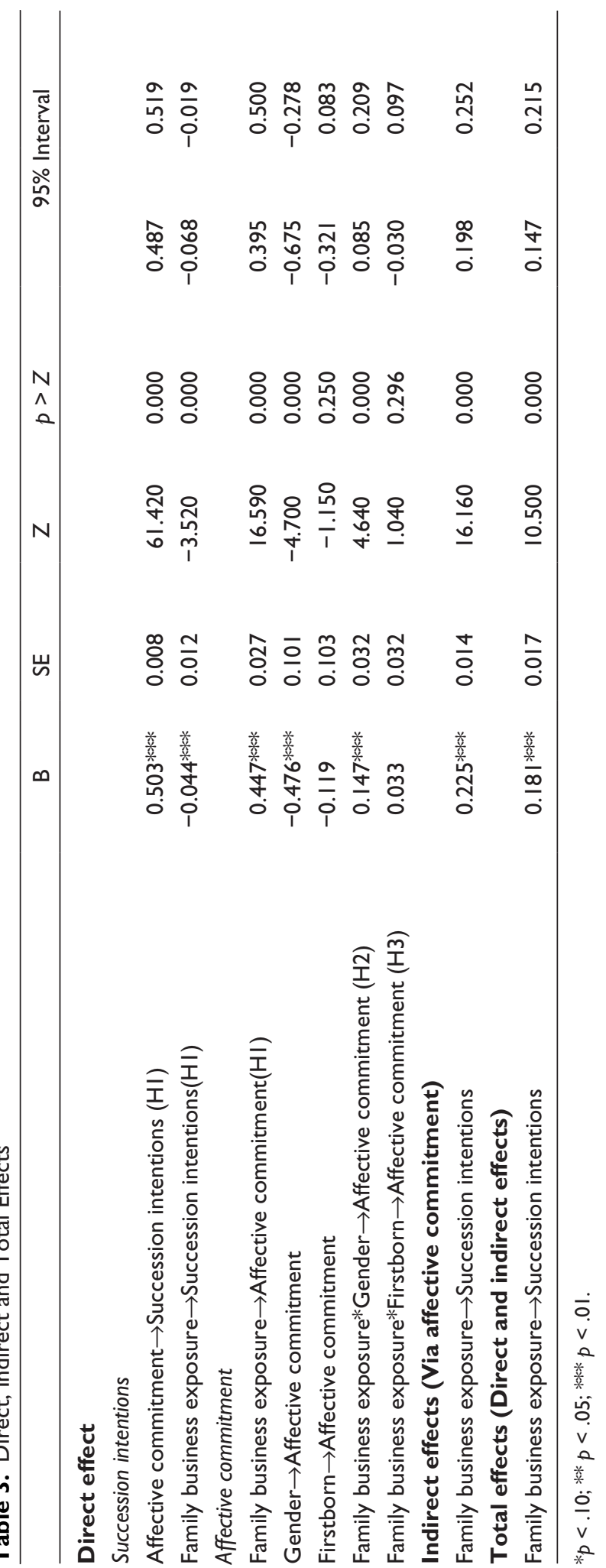


Table 4. Bootstrap Mediation Procedure

\begin{tabular}{lcc}
\hline & $\mathrm{Cl}(\mathrm{P})^{\mathrm{a}}$ & $\mathrm{Cl}(\mathrm{BC})^{\mathrm{b}}$ \\
\hline Family business exposure $\rightarrow$ Succession intentions & $(-0.068 ;-0.017)$ & $(-0.068 ;-0.018)$ \\
Affective commitment $\rightarrow$ Succession intentions & $(0.486 ; 0.52 \mathrm{I})$ & $(0.486 ; 0.522)$ \\
Family business exposure $\rightarrow$ Affective commitment & $(0.393 ; 0.497)$ & $(0.393 ; 0.499)$ \\
Gender $\rightarrow$ Affective commitment & $(-0.704 ;-0.285)$ & $(-0.692 ;-0.274)$ \\
Firstborn $\rightarrow$ Affective commitment & $(-0.338 ; 0.076)$ & $(-0.342 ; 0.07 \mathrm{I})$ \\
Family business exposure*Gender $\rightarrow$ Affective commitment & $(0.088 ; 0.215)$ & $(0.08 \mathrm{I} ; 0.207)$ \\
Family business exposure*Firstborn $\rightarrow$ Affective commitment & $(-0.026 ; 0.10 \mathrm{I})$ & $(-0.026 ; 0.10 \mathrm{I})$ \\
\hline
\end{tabular}

${ }^{\mathrm{a} C}$ Confidence interval (percentile).

${ }^{\mathrm{b}}$ Confidence interval (bias corrected).

\section{Discussion}

Succession is the deliberate outcome of positive intergenerational relationships that include extensive exposure to the family business. This exposure builds slowly over time, creating a long-term commitment to the family firm for the potential successor (Haberman \& Danes, 2007; Stavrou \& Swiercz, 1998; Ward, 1987). In this paper, we contribute to the literature on enterprising families by using an intergenerational succession theory lens to explore children's succession in family firms. As our results show, affective commitment partially mediates the relationship between family business exposure and children's succession intentions thereby reinforcing the importance of commitment in the succession literature (Dawson et al., 2015; Sharma et al., 2003a). We extend our analysis by including the moderating effects of gender and birth order. We discuss our findings below.

\section{The Exposure-Commitment-Succession Intentions Relationship}

Our research finds a positive relationship between family business exposure and affective commitment in potential family firm successors. In the family business context, family business exposure provides a conduit for the exchange of information and access to opportunities, advice, and moral support (Aldrich \& Kim, 2007). Further, exposure to the family business helps children to construct their leadership identity through key interactions with family members (Hytti et al., 2017; Leitch et al., 2017).

This finding extends prior work from sociology research that highlights the influence of enterprising parents on the socialization processes of their children (Sørensen, 2007). This research focuses on the exposure experiences and normative expectations that parents provide to their children and the lasting impact that exposure has on children's subsequent career choices (Kohn et al., 1985; Sewell \& Hauser, 1975). Exposure theorists argue that social reproduction is a byproduct of the familial environment (Sørensen, 2007). While research at the crossroad between entrepreneurship and sociology focuses on the parental influences around self-employment, we extend this logic to the enterprising family environment. Our findings suggest that exposure to (and subsequent familiarity with) the family business causes the child to form an attachment to the family business, and in doing so increases the child's overall intentions to succeed in the family firm.

Results from our study demonstrate the importance of affective commitment on children's succession intentions. Our findings show that affective commitment leads to succession intentions and, in the complete model, partially mediates the family business exposure-succession 
intentions relationship. Potential successors perceive that when their individual goals are aligned with those of the family firm, their career aspirations can be realized by pursuing a career in the family business (Sharma \& Irving, 2005). Using intergenerational solidarity theory, children's affectual solidarity to the family is reflected in their commitment to the business.

Our findings indicate that exposure to the family business is not enough to lead to succession intensions. Instead, we find that exposure only matters when it leads to the development of the child's affective commitment to the family firm. This contribution reconciles contrasting findings (Carr \& Sequeira, 2007; Wang et al., 2018) and suggests that previous work on exposure in family firms (Cabrera-Suárez et al., 2001; Goldberg \& Wooldridge, 1993) might be missing an essential part of the story. However, when exposure leads to the development of affective commitment, we find that the children's commitment to succeed in the family firm is very strong. Future research might explore additional mechanisms that channel the effect of exposure on intention, such as other types of commitment (Dawson et al., 2015). Also, future research might explore how changes in the family institutions (Aldrich et al., Forthcoming) might affect the exposure-commitment-intention process.

\section{The Impact of Gender and Birth Order}

We also find the relationship between family business exposure and affective commitment has a gendered dimension. We find that exposure to the family firm matters for both sexes, but when taking a finer-grained look at this relationship, we find that exposure leads to greater family business commitment more for sons than it does for daughters. This aligns our solidarity-based arguments with extant literature. Sons may benefit more from exposure to the family business because they can more closely identify and tend to spend more time with the parent (typically father) that is running the business (Hoffmann et al., 2015). They also may learn faster or better from parents of the same sex (Bonke \& Esping-Andersen, 2009). Parents provide their children with careerrelated modeling, and in doing so, instill a sense of pride, accomplishment, and satisfaction in the family business (Garcia et al., 2019; Miller \& Le Breton-Miller, 2005). This increases the affective commitment to the family firm, as sons align their social identity with the needs, goals, and values of the family business (Dawson et al., 2015). This finding is similar to the work done by Hoffmann et al. (2015) who explored gendered differences in exposure to role models in entrepreneurship. We extend this literature by adding an intergenerational solidarity-based perspective. Future research might more explicitly take advantage of the psychological ownership literature indicated above and test a process model to shed light on the exposure-commitment relationship and its gendered nuances. They might also explore the role of growing occupational opportunities for women outside the family firm (Aldrich et al., Forthcoming).

Another explanation may be found in the normative cultural practice of primogenitor. Primogenitor is the practice of asymmetric inheritance, where the eldest (typically son) inherits the majority of the estate, in contrast to practices of shared inheritance across all progeny (Menchik, 1980). In the family business context, it refers to the social norm of leaving the business to the eldest son (Calabrò et al., 2018). If primogeniture is followed within the family business, daughters, despite being firstborn, might clearly be aware that the likelihood to become the leader of the family firm is very low; as the overall tendency is that the next male sibling in line will inherit. Thus for daughters, despite their exposure to the family firm, being female decreases their level of affective commitment. Future research could focus specifically on intergenerational succession in a sub-set of family firms that are run solely by women or look at the combination of children and leading enterprising parent's gender. Other work could explore country-level culture or institutions to see the influence that contextual variables have on sons and daughter's succession intentions. 
When we look the moderating impact of birth order on the relationship between family business exposure and affective commitment, contrary to our arguments, we find that there is no significance. Future research could take a closer look at whether the importance of birth order in family business succession has diminished over time (Aldrich et al., Forthcoming). Future studies on birth order in family firms could move beyond the focus of niche and personality to consider a gendered context. It may be that taking a gendered perspective along with birth order may further help explaining succession intentions in family firms.

Finally, we also offer an empirical contribution by finding that the measure of family business exposure that is commonly used in the literature (Carr \& Sequeira, 2007) might contain some inconsistencies. We observed a double-edged sword effect of family business exposure on succession intentions when running our robustness checks, suggesting that family business exposure is a complex and multifaceted concept. Future research could continue to focus on this interesting and contradictory relationship.

\section{Implications and Conclusion}

\section{Limitations and Future Research Directions}

Our study is not without limitations, which need to be borne in mind when interpreting its results. First, we did not have data on the size of the family firm. Firm size is an important variable that is widely used in other succession studies (Stavrou, 1999; Stavrou \& Swiercz, 1998), that is missing from our inquiry. Likewise, future research could focus on the structure of the family, including a fine-grained examination of how the family is involved the development of the family firm successor, as it seems clear that intergenerational relationships significantly influence commitment and succession in family business (Aldrich et al., Forthcoming). Second, our sample is restricted to university students who are by definition more educated than other similar aged possible successors in the overall population, which means that generalizations to the general population of successors in family firms should be made cautiously. In addition, while we have a global sample, we do not consider the influence of culture on our intergenerational relationships in our main theoretical model. Future research could explore the role of cultural dimensions, such as post-materialism (Inglehart, 1997), or performance-based versus socially supportive cultures (Stephan \& Uhlaner, 2010), which might specifically affect solidarity within the family. Fourth, our framework did not capture the role of personal values and their effect on children's succession intentions. Using Schwartz (1992) or sustainable development values, future research could investigate the conflict that rises when children are involved in the family firm and their values and beliefs clash with the organizational culture or the industry in which the firm is located. Finally, in this investigation we use intergenerational solidarity theory as an umbrella theory to explain our family relationships. However, other theoretical lens are also applicable, and these would likely shed new light on the family dynamics inherent in family business succession (Combs et al., 2020; Daspit et al., 2016).

Limitations notwithstanding, our findings have important practical implications for family firm owners, and for aspiring young family business successors. For families, our study helps to clarify the important role played by exposure and affective commitment on a potential family business successor's succession intention. If, in enterprising families, the goal is to keep the business in the family, then our research provides some compelling prescriptive advice around the importance of developing affective commitment in future successors. In addition, our research suggests that gender amplifies the exposure-commitment relationship with exposure having a greater impact on sons. This means that daughters are left out of the succession equation, which could have negative consequences for the enterprising family. 
For scholars, our research begins to address the inconsistencies and conflicting findings in the previous literature on family business exposure. Specifically, we clearly illustrate the importance of commitment in the family business exposure-succession intentions relationship. In addition, our findings demonstrate that the exposure-commitment relationship has a gendered dimension. In conclusion, our study adds a micro-level perspective on intergenerational relationships in the context of the enterprising family. We hope that others will join us in this conversation.

\section{Appendix: Variable Measurements and Reliability Tests}

\begin{tabular}{ll}
\hline Construct & Items \\
\hline $\begin{array}{l}\text { Succession intentions } \\
(\alpha=0.97)\end{array}$ & $\begin{array}{l}\text { I am ready to do anything to take over my parents' firm, } \\
\text { My professional goal is to become a successor in my parents' firm } \\
\text { I will make every effort to become a successor in my parents' firm } \\
\text { I am determined to become a successor in my parents' firm }\end{array}$ \\
$\begin{array}{l}\text { Family business } \\
\text { exposure }\end{array}$ & $\begin{array}{c}\text { Are your parents operationally involved in the company? "Yes" is coded as I, } \\
\text { "No" is coded as 0; " } \\
\text { Is your father or your mother the CEO? "Yes" is coded as I, "No" is coded as } \\
0 ; \text { " } \\
\text { Have you been working for the business of your parents/family? "Yes, I have" } \\
\text { denotes "I" and " } 0 \text { " indicates, "no, I have not". }\end{array}$ \\
$\begin{array}{l}\text { Affective commitment } \\
(\alpha=0.76)\end{array}$ & $\begin{array}{l}\text { I feel emotionally attached to this organization } \\
\text { I connect mainly positive emotions and feeling with the company } \\
\text { Tradition and history play a very important role in our family business }\end{array}$
\end{tabular}

\section{Acknowledgements}

We would like to thank the editor, Bat Batjargal, and the two anonymous referees for helping and guiding us to improve our study by their valuable comments. Daniela Gimenez and Andrea Calabrò would like to thank the Witten Institute for Family Business (WIFU) for their support during the development of the article.

\section{Declaration of Conflicting Interests}

The author(s) declared no potential conflicts of interest with respect to the research, authorship, and/or publication of this article.

\section{Funding}

The author(s) received no financial support for the research, authorship, and/or publication of this article.

\section{ORCID IDs}

Daniela Gimenez-Jimenez (iD https://orcid.org/0000-0003-1704-1354

Tommaso Minola (iD https://orcid.org/0000-0003-0337-9741

Andrea Calabrò (iD https://orcid.org/0000-0002-6969-3306

Lucio Cassia (iD https://orcid.org/0000-0003-0602-3409 


\section{Notes}

1. The countries included in this study are Argentina, Austria, Australia, Belgium, Brazil, Canada, Colombia, Denmark, England, Estonia, Finland, France, Germany, Greece, Hungary, Israel, Italy, Japan, Lichtenstein, Luxemburg, Malaysia, Mexico, Netherland, Poland, Portugal, Romania, Russia, Scotland, Singapore, Slovenia, Spain, Switzerland, and the United States.

2. We thank an anonymous reviewer for the help received with this point.

3. We thank the GUESSS team for the assistance on this.

4. The results from these additional tests are available from the authors, upon request.

\section{References}

Aldrich, H. E., Brumana, M., Campopiano, G., \& Minola, T. (Forthcoming). Embedded but not asleep: entrepreneurship and family business research in the 21st century. Journal of Family Business Strategy.

Aldrich, H. E., \& Kim, P. H. (2007). A life course perspective on occupational inheritance: Self-employed parents and their children. In M. Ruef \& M. Lounsbury (Eds.), The sociology of entrepreneurship (research in the sociology of organizations) (Vol. 25, pp. 33-82). Emerald Group Publishing Limited.

Allen, N. J., \& Meyer, J. P. (1990). The measurement and antecedents of affective, continuance and normative commitment to the organization. Journal of Occupational and Organizational psychology, 63(1), 1-18. https://doi.org/10.1111/j.2044-8325.1990.tb00506.x

Anna, A. L., Chandler, G. N., Jansen, E., \& Mero, N. P. (2000). Women business owners in traditional and non-traditional industries. Journal of Business Venturing, 15(3), 279-303. https://doi.org/10.1016/ S0883-9026(98)00012-3

Aragon-Amonarriz, C., Arredondo, A. M., \& Iturrioz-Landart, C. (2019). How can responsible family ownership be sustained across generations? A family social capital approach. Journal of Business Ethics, 159(1), 161-185. https://doi.org/10.1007/s10551-017-3728-7

Barbera, F., Shi, H. X., Agarwal, A., \& Edwards, M. (2020). The family that prays together stays together: toward a process model of religious value transmission in family firms. Journal of Business Ethics, 163(4), 661-673. https://doi.org/10.1007/s10551-019-04382-7

Barnett, T., Long, R. G., \& Marler, L. E. (2012). Vision and exchange in intra-family succession: effects on procedural justice climate among nonfamily managers. Entrepreneurship Theory and Practice, 36(6), 1207-1225. https://doi.org/10.1111/j.1540-6520.2012.00546.x

Beckert, J. (2007). The "Longue Durée" of inheritance law: discourses and institutional development in france, germany, and the united states since 1800. Archives Européennes de Sociologie/European Journal of Sociology/Europäisches Archiv für Soziologie, 48(1), 79-120.

Bengtson, V. L. (2001). Beyond the nuclear family: the increasing importance of multigenerational bonds: The burgess award lecture. Journal of Marriage and Family, 63(1), 1-16. https://doi.org/10.1111/j. 1741-3737.2001.00001.x

Bengtson, V. L., \& Roberts, R. E. (1991). Intergenerational solidarity in aging families: an example of formal theory construction. Journal of Marriage and the Family, 53(4), 856-870. https://doi.org/10. $2307 / 352993$

Bird, M., \& Zellweger, T. (2018). Relational embeddedness and firm growth: comparing spousal and sibling entrepreneurs. Organization Science, 29(2), 264-283. https://doi.org/10.1287/orsc.2017. 1174

Birley, S. (1986). Succession in the family firm: the inheritor's view. Journal of Small Business Management, 24,36 .

Birley, S. (2002). Attitudes of owner-managers' children towards family and business issues. Entrepreneurship Theory and Practice, 26(3), 5-19. https://doi.org/10.1177/104225870202600301 
Bloemen-Bekx, M., Van Gils, A., Lambrechts, F., \& Sharma, P. (2019). Nurturing offspring's affective commitment through informal family governance mechanisms. Journal of Family Business Strategy, 100309. https://doi.org/10.1016/j.jfbs.2019.100309

Bonke, J., \& Esping-Andersen, G. (2009). Parental investments in children: How educational homogamy and bargaining affect time allocation. European Sociological Review, 10(20), 1-13.

Brim, O. G. (1968). Socialization through the life cycle. In P. Priestley \& M. Vanstone (Eds.), Offenders or Citizens? Readings in Rehabilitation. Routledge Taylor and Francis Group.

Brush, C. G. (1992). Research on women business owners: Past trends, future directions, and a new perspective. Entrepreneurship Theory and Practice, 16(4), 5-30.

Cabrera-Suárez, K., De Saá-Pérez, P., \& García-Almeida, D. (2001). The succession process from a resource-and knowledge-based view of the family firm. Family Business Review, 14(1), 37-46. https://doi.org/10.1111/j.1741-6248.2001.00037.x

Cabrera-Suárez, M. K., Déniz-Déniz, M. d. L. C., \& Martín-Santana, J. D. (2014). The setting of nonfinancial goals in the family firm: the influence of family climate and identification. Journal of Family Business Strategy, 5(3), 289-299. https://doi.org/10.1016/j.jfbs.2014.05.003

Calabrò, A., Minichilli, A., Amore, M. D., \& Brogi, M. (2018). The courage to choose! Primogeniture and leadership succession in family firms. Strategic Management Journal, 39(7), 2014-2035. https://doi. org/10.1002/smj.2760

Carr, J. C., \& Sequeira, J. M. (2007). Prior family business exposure as intergenerational influence and entrepreneurial intent: a theory of planned behavior approach. Journal of Business Research, 60(10), 1090-1098. https://doi.org/10.1016/j.jbusres.2006.12.016

Cha, Y. (2013). Overwork and the persistence of gender segregation in occupations. Gender \& Society, 27(2), 158-184. https://doi.org/10.1177/0891243212470510

Chadwick, K., \& Ward, J. (1987). Determinants of consumer satisfaction with education: Implications for college and university administrators. College and University, 62(3), 236-246.

Combs, J. G., Shanine, K. K., Burrows, S., Allen, J. S., \& Pounds, T. W. (2020). What do we know about business families? Setting the stage for leveraging family science theories. Family Business Review, 33(1), 38-63. https://doi.org/10.1177/0894486519863508

Criaco, G., Sieger, P., Wennberg, K., Chirico, F., \& Minola, T. (2017). Parents'performance in entrepreneurship as a "double-edged sword" for the intergenerational transmission of entrepreneurship. Small Business Economics, 49(4), 841-864. https://doi.org/10.1007/s11187-017-9854-x

Daspit, J. J., Holt, D. T., Chrisman, J. J., \& Long, R. G. (2016). Examining family firm succession from a social exchange perspective: A multiphase, multistakeholder review. Family Business Review, 29(1), 44-64.

Dawson, A., Sharma, P., Irving, P. G., Marcus, J., \& Chirico, F. (2015). Predictors of later-generation family members' commitment to family enterprises'. Entrepreneurship Theory and Practice, 39(3), 545569. https://doi.org/10.1111/etap.12052

De Massis, A., Chua, J. H., \& Chrisman, J. J. (2008). Factors preventing intra-family succession. Family Business Review, 21(2), 183-199. https://doi.org/10.1111/j.1741-6248.2008.00118.x

Decker, R. A., Haltiwanger, J., Jarmin, R. S., \& Miranda, J. (2017). Declining dynamism, allocative efficiency, and the productivity slowdown. American Economic Review, 107(5), 322-326.

Eagly, A. H., \& Wood, W. (2011). Feminism and the evolution of sex differences and similarities. Sex Roles, 64(9-10), 758-767. https://doi.org/10.1007/s11199-011-9949-9

Eddleston, K. A., Kellermanns, F. W., \& Zellweger, T. M. (2012). Exploring the entrepreneurial behavior of family firms: Does the stewardship perspective explain differences? Entrepreneurship Theory and Practice, 36(2), 347-367. https://doi.org/10.1111/j.1540-6520.2010.00402.x

Edelman, L. F., Manolova, T., Shirokova, G., \& Tsukanova, T. (2016). The impact of family support on young entrepreneurs' start-up activities. Journal of Business Venturing, 31(4), 428-448. https://doi. org/10.1016/j.jbusvent.2016.04.003 
Fitz-Koch, S., \& Nordqvist, M. (2017). The reciprocal relationship of innovation capabilities and socioemotional wealth in a family firm. Journal of Small Business Management, 55(4), 547-570. https://doi.org/10.1111/jsbm.12343

Garcia, P. R. J. M., Sharma, P., De Massis, A., Wright, M., \& Scholes, L. (2019). Perceived parental behaviors and next-generation engagement in family firms: A social cognitive perspective. Entrepreneurship Theory and Practice, 43(2), 224-243. https://doi.org/10.1177/1042258718796087

Glover, J. L. (2014). Gender, power and succession in family farm business. International Journal of Gender and Entrepreneurship, 6(3), 276-295. https://doi.org/10.1108/IJGE-01-2012-0006

Goldberg, S. D., \& Wooldridge, B. (1993). Self-confidence and managerial autonomy: Successor characteristics critical to succession in family firms. Family Business Review, 6(1), 55-73. https://doi. org/10.1111/j.1741-6248.1993.00055.x

Habbershon, T. G., \& Pistrui, J. (2002). Enterprising families domain: Family-influenced ownership groups in pursuit of transgenerational wealth. Family Business Review, 15(3), 223-237. https://doi.org/10. 1111/j.1741-6248.2002.00223.x

Haberman, H., \& Danes, S. M. (2007). Father-daughter and father-son family business management transfer comparison: family FIRO model application. Family Business Review, 20(2), 163-184. https://doi. org/10.1111/j.1741-6248.2007.00088.x

Hair, J. F., Black, W. C., Babin, B. J., Anderson, R. E., \& Tatham, R. L. (2006). Multivariate data analysis (Vol. 6). Pearson Prentice Hall.

Handler, W. C. (1989). Methodological issues and considerations in studying family businesses. Family Business Review, 2(3), 257-276. https://doi.org/10.1111/j.1741-6248.1989.00257.x

Handler, W. C. (1992). The succession experience of the next generation. Family Business Review, 5(3), 283-307. https://doi.org/10.1111/j.1741-6248.1992.00283.x

Handler, W. C. (1994). Succession in family business: a review of the research. Family Business Review, 7(2), 133-157. https://doi.org/10.1111/j.1741-6248.1994.00133.x

Henssen, B., \& Ikävalko, M. (2014). CEOs' identification with the family firm and their affective commitment: exploring the role of targets of psychological ownership (co-operation within and amongst family businesses) [Conference session]. Paper presented at the IFERA, Lappeenranta, Finland.

Hoffmann, A., Junge, M., \& Malchow-Møller, N. (2015). Running in the family: parental role models in entrepreneurship. Small Business Economics, 44(1), 79-104. https://doi.org/10.1007/s11187-0149586-0

Hytti, U., Alsos, G. A., Heinonen, J., \& Ljunggren, E. (2016). Navigating the family business: A gendered analysis of identity construction of daughters. International Small Business Journal: Researching Entrepreneurship, 35(6), 665-686. https://doi.org/10.1177/0266242616675924

Inglehart, R. (1997). Modernization and postmodernization: Cultural, economic, and political change in 43 societies. Princeton University Press.

Jaskiewicz, P., Combs, J. G., \& Rau, S. B. (2015). Entrepreneurial legacy: toward a theory of how some family firms nurture transgenerational entrepreneurship. Journal of Business Venturing, 30(1), 29-49. https://doi.org/10.1016/j.jbusvent.2014.07.001

Jaskiewicz, P., Combs, J. G., Shanine, K. K., \& Kacmar, K. M. (2017). Introducing the family: A review of family science with implications for management research. Academy of Management Annals, 11(1), 309-341. https://doi.org/10.5465/annals.2014.0053

Jaskiewicz, P., \& Dyer, W. G. (2017). Addressing the elephant in the room: Disentangling family heterogeneity to advance family business research. Family Business Review, 30(2), 111-118. https:// doi.org/10.1177/0894486517700469

Jaskiewicz, P., \& Luchak, A. A. (2013). Explaining performance differences between family firms with family and nonfamily ceos: It's the nature of the tie to the family that counts! Entrepreneurship Theory and Practice, 37(6), 1361-1367. https://doi.org/10.1111/etap.12070 
Jaskiewicz, P., Uhlenbruck, K., Balkin, D. B., \& Reay, T. (2013). Is nepotism good or bad? Types of nepotism and implications for knowledge management. Family Business Review, 26(2), 121-139. https://doi.org/10.1177/0894486512470841

Jayantilal, S., Jorge, S. F., \& Palacios, T. M. B. (2016). Effects of sibling competition on family firm succession: A game theory approach. Journal of Family Business Strategy, 7(4), 260-268. https://doi. org/10.1016/j.jfbs.2016.10.001

Kohn, M. L., Slomczynski, K. M., \& Schoenbach, C. (1985). Social stratification and the transmission of values in the family: A cross-national assessment. Sociological Forum, 1, 73-102. https://doi.org/10. 1007/BF01115074

Leitch, C., Harrison, R., \& McAdam, M.(2017). Identity work, swift trust and gender: The role of womenonly leadership development programmes. In C. Henry, T. Nelson, \& K. Lewis (Eds.), The routledge companion to global female entrepreneurship (pp. 233-252). Routledge.

Litz, R. A., \& Turner, N. (2013). Sins of the father's firm: Exploring responses to inherited ethical dilemmas in family business. Journal of Business Ethics, 113(2), 297-315. https://doi.org/10.1007/s10551-012$1305-7$

Liñán, F., \& Chen, Y.-W. (2009). Development and cross-cultural application of a specific instrument to measure entrepreneurial intentions. Entrepreneurship Theory and Practice, 33(3), 593-617. https:// doi.org/10.1111/j.1540-6520.2009.00318.x

Long, R. G., \& Mathews, K. M. (2011). Ethics in the family firm: Cohesion through reciprocity and exchange. Business Ethics Quarterly, 21(2), 287-308. https://doi.org/10.5840/beq201121217

Mancini, J. A., \& Blieszner, R. (1989). Aging parents and adult children: Research themes in intergenerational relations. Journal of Marriage and the Family, 51(2), 275-290. https://doi.org/10. $2307 / 352492$

Mangen, D. J., Bengtson, V. L., \& Landry Jr, P. H. (1988). Measurement of intergenerational relations. Sage Publications, Inc.

McMullen, J. S., \& Warnick, B. J. (2015). Article commentary: To nurture or groom? the parent-founder succession dilemma. Entrepreneurship Theory and Practice, 39(6), 1379-1412.

Meier, O., \& Schier, G. (2016). The early succession stage of a family firm: Exploring the role of agency rationales and stewardship attitudes. Family Business Review, 29(3), 256-277.

Memili, E., Chang, E. P. C., Kellermanns, F. W., \& Welsh, D. H. B. (2015). Role conflicts of family members in family firms. European Journal of Work \& Organizational Psychology, 24(1), 143-151. https://doi. org/10.1080/1359432X.2013.839549

Menchik, P. L. (1980). Primogeniture, equal sharing, and the US distribution of wealth. The Quarterly Journal of Economics, 94(2), 299-316. https://doi.org/10.2307/1884542

Meyer, J. P., \& Herscovitch, L. (2001). Commitment in the workplace: Toward a general model. Human Resource Management review, 11(3), 299-326. https://doi.org/10.1016/S1053-4822(00)00053-X

Miller, D., \& Breton-Miller, L, I. (2005). Management insights from great and struggling family businesses. Long Range Planning, 38(6), 517-530. https://doi.org/10.1016/j.lrp.2005.09.001

Miller, D., Steier, L., \& Le Breton-Miller, L, I. (2003). Lost in time: Intergenerational succession, change, and failure in family business. Journal of Business Venturing, 18(4), 513-531. https://doi.org/10. 1016/S0883-9026(03)00058-2

Minola, T., Criaco, G., \& Obschonka, M. (2016). Age, culture, and self-employment motivation. Small Business Economics, 46(2), 187-213. https://doi.org/10.1007/s11187-015-9685-6

Moore, K. A., Chalk, R., Scarpa, J., \& Vandivere, S. (2002). Preliminary research on family strengths. Child Trends.

Mungai, E., \& Velamuri, S. R. (2011). Parental entrepreneurial role model influence on male offspring: Is it always positive and when does it occur? Entrepreneurship Theory and Practice, 35(2), 337-357. https://doi.org/10.1111/j.1540-6520.2009.00363.x 
Nelson, T., \& Constantinidis, C. (2017). Sex and gender in family business succession research: A review and forward agenda from a social construction perspective. Family Business Review, 30(3), 219-241. https://doi.org/10.1177/0894486517715390

Nordqvist, M., \& Melin, L. (2010). Entrepreneurial families and family firms. Entrepreneurship \& Regional Development, 22(3-4), 211-239. https://doi.org/10.1080/08985621003726119

Nunnally, J. C., \& Bernstein, I. H. (1994). Psychological theory. MacGraw-Hill.

Özcan, B. (2011). Only the lonely? The influence of the spouse on the transition to self-employment. Small Business Economics, 37(4), 465-492. https://doi.org/10.1007/s11187-011-9376-x

Parker, S. C., \& Van Praag, C. M. (2012). The entrepreneurs mode of entry: Business takeover or new venture start? Journal of Business Venturing, 27(1), 31-46. https://doi.org/10.1016/j.jbusvent.2010. 08.002

Paulhus, D. L., Trapnell, P. D., \& Chen, D. (1999). Birth order effects on personality and achievement within families. Psychological Science, 10(6), 482-488. https://doi.org/10.1111/1467-9280.00193

Pierce, J. L., Kostova, T., \& Dirks, K. T. (2001). Toward a theory of psychological ownership in organizations. Academy of Management Review, 26(2), 298-310. https://doi.org/10.5465/amr.2001. 4378028

Pierce, J. L., Rubenfeld, S. A., \& Morgan, S. (1991). Employee ownership: A conceptual model of process and effects. Academy of Management Review, 16(1), 121-144. https://doi.org/10.5465/amr.1991. 4279000

Pittino, D., Visintin, F., \& Lauto, G. (2018). Fly away from the nest? A configurational analysis of family embeddedness and individual attributes in the entrepreneurial entry decision by next-generation members. Family Business Review, 31(3), 271-294. https://doi.org/10.1177/0894486518773867

Podsakoff, P. M., MacKenzie, S. B., Lee, J.-Y., \& Podsakoff, N. P. (2003). Common method biases in behavioral research: A critical review of the literature and recommended remedies. Journal of Applied Psychology, 88(5), 879-903. https://doi.org/10.1037/0021-9010.88.5.879

Powell, G. N. (2011). The gender and leadership wars. Organizational Dynamics, 40(1), 1-9. https://doi. org/10.1016/j.orgdyn.2010.10.009

Roberts, R. E., Richards, L. N., \& Bengtson, V. (1991). Intergenerational solidarity in families: Untangling the ties that bind. Marriage \& Family Review, 16(1-2), 11-46.

Rohde, P. A., Atzwanger, K., Butovskaya, M., Lampert, A., Mysterud, I., \& Sanchez-Andres, A. (2003). Perceived parental favoritism, closeness to kin, and the rebel of the family the effects of birth order and sex. Evolution and Human Behavior, 24(4), 261-276. https://doi.org/10.1016/S1090-5138(03) 00033-3

Schröder, E., Schmitt-Rodermund, E., \& Arnaud, N. (2011). Career choice intentions of adolescents with a family business background. Family Business Review, 24(4), 305-321. https://doi.org/10.1177/ 0894486511416977

Schwartz, S. H. (1992). Universals in the content and structure of values: Theoretical advances and empirical tests in 20 countries. Advances in Experimental Social Psychology, 25(1), 1-65.

Sewell, W. H., \& Hauser, R. M. (1975). Education, occupation, and earnings: Achievement in the early career. Taylor Francis.

Sharma, P., Chrisman, J. J., \& Chua, J. H. (2003a). Predictors of satisfaction with the succession process in family firms. Journal of Business Venturing, 18(5), 667-687. https://doi.org/10.1016/S0883-9026( 03)00015-6

Sharma, P., Chrisman, J. J., \& Chua, J. H. (2003b). Succession planning as planned behavior: Some empirical results. Family Business Review, 16(1), 1-15. https://doi.org/10.1111/j.1741-6248.2003. 00001.x

Sharma, P., \& Irving, P. G. (2005). Four bases of family business successor commitment: Antecedents and consequences. Entrepreneurship Theory and Practice, 29(1), 13-33. https://doi.org/10.1111/j.15406520.2005.00067.x 
Shinnar, R. S., Cho, S., \& Rogoff, E. G. (2013). Outcomes of family involvement in minority owned family businesses. Journal of Family Business Strategy, 4(1), 22-33. https://doi.org/10.1016/j.jfbs.2012.12.001

Sieger, P., Fueglistaller, U., \& Zellweger, T. (2014). Student entrepreneurshipacross the globe: a look at intentions and activities. St. Gallen: KMU-HSG.

Sieger, P., \& Minola, T. (2017). The family's financial support as a 'poisoned gift': A family embeddedness perspective on entrepreneurial intentions. Journal of Small Business Management, 55(1), 179-204. https://doi.org/10.1111/jsbm.12273

Sieger, P., \& Monsen, E. (2015). Founder, academic, or employee? A nuanced study of career choice intentions. Journal of Small Business Management, 53(1), 30-57. https://doi.org/10.1111/jsbm.12181

Sieger, P., Zellweger, T., \& Aquino, K. (2013). Turning agents into psychological principals: Aligning interests of non-owners through psychological ownership. Journal of Management Studies, 50(3), 361-388. https://doi.org/10.1111/joms. 12017

Silverstein, M., \& Bengtson, V. L. (1997). Intergenerational solidarity and the structure of adult child-parent relationships in American families. American Journal of Sociology, 103(2), 429-460. https://doi.org/ $10.1086 / 231213$

Starrels, M. E., Ingersoll-Dayton, B., Neal, M. B., \& Yamada, H. (1995). Intergenerational solidarity and the workplace: Employees' caregiving for their parents. Journal of Marriage and the Family, 57(3), 751-762. https://doi.org/10.2307/353929

Sørensen, J. B. (2007). Closure and exposure: Mechanisms in the intergenerational transmission of selfemployment. In M. Ruef \& M. Lounsbury (Eds.), The Sociology of Entrepreneurship (Research in the Sociology of Organizations) (Vol. 25, pp. 83-124). Emerald Group Publishing Limited.

The Economist. (2015). Reluctant heirs. (15.12.2017). https://www.economist.com/business/2015/12/03/ reluctant-heirs

Stavrou, E. T. (1999). Succession in family businesses: Exploring the effects of demographic factors on offspring intentions to join and take over the business. Journal of Small Business Management, 37(3), 43.

Stavrou, E. T., \& Swiercz, P. M. (1998). Securing the future of the family enterprise: A model of offspring intentions to join the business. Entrepreneurship Theory and Practice, 23(2), 19-40. https://doi.org/ $10.1177 / 104225879802300202$

Stephan, U., \& Uhlaner, L. M. (2010). Performance-based vs socially supportive culture: A cross-national study of descriptive norms and entrepreneurship. Journal of International Business Studies, 41(8), 1347-1364. https://doi.org/10.1057/jibs.2010.14

Sulloway, F. J. (1996). Born to rebel: Birth order, family dynamics, and creative lives. Pantheon Books.

Sulloway, F. J. (2001). Birth order, sibling competition, and human behavior. In Conceptual challenges in evolutionary psychology (pp. 39-83). Springer.

Townsend, D. M., DeTienne, D., Yitshaki, R., \& Arthurs, J. D. (2009). The psychological ownership of entrepreneurial organizations: Theoretical and model development. Frontiers of Entrepreneurship Research, 29(6), 3.

Umans, I., Lybaert, N., Steijvers, T., \& Voordeckers, W. (2019). The influence of transgenerational succession intentions on the succession planning process: The moderating role of high-quality relationships. Journal of Family Business Strategy, 100269. https://doi.org/10.1016/j.jfbs.2018.12.002

Venter, E., Boshoff, C., \& Maas, G. (2005). The influence of successor-related factors on the succession process in small and medium-sized family businesses. Family Business Review, 18(4), 283-303. https://doi.org/10.1111/j.1741-6248.2005.00049.x

Verver, M., \& Koning, J. (2018). Toward a kinship perspective on entrepreneurship. Entrepreneurship Theory and Practice, 42(4), 631-666. https://doi.org/10.1177/1042258718783431

Wang, D., Wang, L., \& Chen, L. (2018). Unlocking the influence of family business exposure on entrepreneurial intentions. International Entrepreneurship and Management Journal, 14(4), 951974. https://doi.org/10.1007/s11365-017-0475-2 
Ward, J. L. (1987). Keeping the family business healthy: How to plan for continuing growth, profitability, and family leadership. Palgrave Macmillan.

Zahra, S. A. (2012). Organizational learning and entrepreneurship in family firms: Exploring the moderating effect of ownership and cohesion. Small Business Economics, 38(1), 51-65. https://doi.org/10.1007/ s11187-010-9266-7

Zajonc, R. B., \& Markus, G. B. (1975). Birth order and intellectual development. Psychological Review, 82(1), 74-88. https://doi.org/10.1037/h0076229

Zellweger, T., Richards, M., Sieger, P., \& Patel, P. C. (2016). How much am I expected to pay for my parents firm? An institutional logics perspective on family discounts. Entrepreneurship Theory and Practice, 40(5), 1041-1069. https://doi.org/10.1111/etap.12161

Zellweger, T., Sieger, P., \& Halter, F. (2011). Should I stay or should I go? Career choice intentions of students with family business background. Journal of Business Venturing, 26(5), 521-536. https://doi. org/10.1016/j.jbusvent.2010.04.001

\section{Author Biographies}

Daniela Gimenez is a postdoctoral researcher and a lecturer at the Chair for Corporate Sustainability at the Technische Universität München (TUM School of Management, Germany). She received her doctoral degree at Witten/Herdecke University (Germany) and her master degree in Entrepreneurship and Management from the Autonomous University of Barcelona (Spain. During her doctoral thesis, she was a visiting scholar at Bentley University (United States). Daniela dedicates her research and teaching to sustainable entrepreneurship as well as women in entrepreneurship and in family businesses. She is interested in the understanding of institutions (e.g., family, culture, regulations and policies) and the main antecedents of entrepreneurial processes.

Linda F. Edelman is a Full Professor at Bentley University, and currently serves as the chair of the Management Department. She received her MBA and DBA from Boston University. Before coming to Bentley, Linda studied at London Business School and was a research fellow at the Warwick Business School. Her research examines small firms, women and nascent entrepreneurs. Linda serves on four editorial boards and has co-edited three special issues on women in entrepreneurship. She is the author of four books and over 75 scholarly journal articles and book chapters. She teaches courses in strategic management and strategic innovation to undergraduates, graduates, doctoral students, and executives.

Tommaso Minola is associate professor at the Department of Management, Information and Production Engineering (DIGIP), and co-founder and director of the Center for Young and Family Enterprise (CYFE) at the University of Bergamo. In his research, Tommaso looks at the family and the university as contexts particularly relevant for venture creation, development and firm performance. His works have been published in leading academic journals in management, innovation, entrepreneurship and small business, such as Journal of Management Studies, Research Policy, Entrepreneurship Theory and Practice, Strategic Entrepreneurship Journal, Small Business Economics, Journal of Small Business Management, amongst others.

Andrea Calabrò is Co-Director of the IPAG Entrepreneurship \& Family Business Center and Professor of Family Business \& Entrepreneurship at IPAG Business School, France. He is Global Academic Director of the STEP (Successful Transgenerational Entrepreneurship Practices) Project Global Consortium. He has published journal articles on family firms, internationalization, and corporate governance in leading international journals such as: Strategic Management 
Journal, Entrepreneurship Theory \& Practice, Family Business Review, Harvard Business Review, and Journal of Business Ethics.

Lucio Cassia is full professor at the Department of Management, Information and Production Engineering (DIGIP) and founder and chairman of the Center for Young and Family Enterprise (CYFE) of the University of Bergamo. He teaches Strategic Management and Entrepreneurship. $\mathrm{He}$ is currently leading research on venture creation, growth strategy, and family business governance and succession. Lucio Cassia is author of many books and more than 150 papers in academic and professional journals. 